\title{
Epidemiology of leptospirosis at Sorocaba Zoo, São Paulo state, Southeastern Brazil ${ }^{1}$
}

\author{
Leila S. Ullmann ${ }^{2 *}$, Ramiro N.D. Neto ${ }^{3}$, Rodrigo H.F. Teixeira ${ }^{3}$, Adauto V. Nunes ${ }^{3}$, \\ Rodrigo C. Silva ${ }^{2}$, Virgínia B. Pereira-Richini ${ }^{2}$ and Helio Langoni ${ }^{2}$
}

\begin{abstract}
Ullmann L.S., Neto R.N.D., Teixeira R.H.F., Nunes A.V., Silva R.C., Pereira-Richini V.B. \& Langoni H. 2012. Epidemiology of leptospirosis at Sorocaba Zoo, São Paulo state, Southeastern Brazil. Pesquisa Veterinária Brasileira 32(11):1174-1178. Departamento de Higiene Veterinária e Saúde Pública, Faculdade de Medicina Veterinária e Zootecnia, Universidade Estadual Paulista, Campus Botucatu, Distrito de Rubião Junior s/n, Botucatu, SP 18618-970, Brazil. *Corresponding author: leila_ullmann@yahoo.com.br

Leptospirosis is considered a worldwide distributed zoonosis, caused by the bacteria Leptospira spp. Since several species of wildlife animals are reportedly reservoirs, the aim of the present study was to know the epidemiology of leptospirosis at the Sorocaba Zoo, Southern Brazil. Serum samples of wild mammals from Artiodactyla, Carnivora, Didelphimorphia, Diprotodontia, Perissodactyla, Pilosa, Primates, Proboscidea and Rodentia orders, kept in captivity as well as from zoological staff were assayed by microscopic agglutination test (MAT). Whole blood, urine and tissue samples from wild mammals and synanthropic animals were assayed by polymerase chain reaction (PCR). An epidemiological survey was applied to evaluate the risk factors for animal infection and staff level of knowledge on leptospirosis. A total of 13/229 (5.68\%; CI95\% 3.37-9.47\%) serum samples from wild mammals were reagent on MAT. Serology from synanthropic animals, zoo staff and molecular analysis of animal samples were all negative. Leptospirosis knowledge of zoo park staff was considered medium. In conclusion, leptospiral infection occurs at the studied zoo but due to the low occurrence found, the lowest reported in literature, wild captive mammals do not act as source of infection of leptospirosis to other animals and human beings.
\end{abstract}

INDEX TERMS: Wild mammals, Leptospira spp., leptospirosis, MAT, zoonosis.

RESUMO.- [Epidemiologia da leptospirose no Zoológico de Sorocaba, Estado de São Paulo, Sudeste do Brasil.] A leptospirose é considerada uma zoonose de distribuição mundial, causada por bactérias do gênero Leptospira spp. Uma vez que muitas espécies de animais selvagens são consideradas como reservatórios, o objetivo do presente estudo foi conhecer a epidemiologia da leptospirose no Zoológico de Sorocaba, sudeste do Brasil. Amostras de soro de mamíferos selvagens cativos das ordens Artiodactyla, Carnivora, Didelphimorphia, Diprotodontia, Perissodactyla, Pilosa, Primates, Proboscidea e Rodentia, assim como dos funcionários

\footnotetext{
${ }^{1}$ Received on December 29, 2011.

Accepted for publication on May 29, 2012.

${ }^{2}$ Departmento de Higiene Veterinária e Saúde Pública, Faculdade de Medicina Veterinária e Zootecnia, Universidade Estadual Paulista (Unesp), Campus Botucatu, Distrito de Rubião Junior s/n, Botucatu, SP 18618-970, Brazil. *Corresponding author: leila_ullmann@yahoo.com.br

${ }^{3}$ Zoológico Municipal “Quinzinho de Barros”, Rua Teodoro Kasel 883, Jardim Hortência, Sorocaba, SP 18020-268, Brazil.
}

do zoo foram analisados pela soroaglutinação microscópica (SAM). Sangue total, urina e amostras de tecidos dos animais selvagens e sinantrópicos foram analisados pela reação em cadeia pela polimerase (PCR). Um questionário epidemiológico foi aplicado para se avaliar os fatores de risco de infecção por leptospira dos animais e também para avaliar o grau de conhecimento dos funcionários do parque sobre a leptospirose. Um total de 13/229 (5,68\%; CI95\% 3.37-9.47\%) amostras de soro dos mamíferos selvagens foram reagentes na SAM. A sorologia dos animais sinantrópicos, funcionários do zoológico e a análise molecular lograram-se negativas. 0 conhecimento dos funcionários sobre a leptospirose foi considerado médio. Em conclusão, a infecção leptospírica ocorre no parque zoológico estudado, porém devido à baixa ocorrência encontrada, a menor descrita na literatura, os mamíferos cativos não desempenham um papel de fonte de infecção para outros animais e para o homem.

TERMOS DE INDEXAÇÃO: Animais selvagens, Leptospira spp., leptospirose, SAM, zoonose. 


\section{INTRODUCTION}

Leptospirosis is considered a worldwide zoonosis, present in all continents, except Antarctic (Adler \& Moctezuma 2010), highlighting among emerging and re-emerging diseases (Langoni et al. 1998, Bharadwaj 2004), with more than 500 thousand severe cases reported annually around the world (Bourhy et al. 2010), considered endemic in Brazil (SVS 2010).

The disease is caused by Spirochetales order bacteria, Leptospiraceae family, Leptospira genus (Levett 2001). Leptospira species are divided into 13 pathogenic and six saprophytic species (Adler \& Moctezuma 2010), divided into more than 200 serovars. Serotyping has been recognized as an essential tool in clinic and epidemiological investigations and it can indicate the reservoir involved in the disease transmission (Ko et al. 2009).

Infection occurs through the contact with contaminated water mainly with carriers' urine (Bharti et al. 2003). Many domestic and wild animals get infected becoming renal carriers and potential reservoirs (Sharma et al. 2003).

Zoological parks are usually placed in urban centers where thousands of people have access in visits or as staff. There are 127 zoo parks in Brazil and 32 are in São Paulo State (SZB, 2012). Besides conservationist role, zoos assume importance in environmental education and contribute to the knowledge of the native and exotic species. Captive environment allows improving diagnosis techniques as they are important source of information due to the wide species variety and the facilities on animal handling comparing to field studies. Infectious diseases studies, especially zoonotic ones, must be performed in captive facilities to know the epidemiology of these diseases in such places improving control and prevention measures.

Almost all young mammals and marsupials are susceptible to leptospirosis. Due to the endemic characteristic of leptospirosis in Brazil, seroprevalence studies were performed in some Brazilian zoos including: Rio de Janeiro Zoo (Lilenbaum et al. 2002), São Paulo Zoo Park Foundation (Corrêa et al. 2004), Bela Vista Sanctuary (Guerra-Neto et al. 2004), Uberaba Zoo (Esteves et al. 2005), Aracaju Zoo (Pimentel et al. 2009), Ribeirão Preto Zoo (Silva et al. 2010); and worldwide at Korean Municipal Zoo (Jung et al. 2007) and Chapultec Zoo (Luna-Alvarez et al. 1996).

Accordingly, the present study aimed to evaluate the epidemiology of leptospirosis at the Sorocaba Zoo, analyzing serum, blood, urine and tissues samples from captive mammals and synanthropic animals caught at the park through different diagnosis methods. Besides Leptospira spp. antibodies were researched in samples from zoo staff and an epidemiological inquiry was performed to evaluate infection risk factors.

\section{MATERIALS AND METHODS}

The "Quinzinho de Barros" Municipal Zoo Park (QBMZP), known as Sorocaba Zoo, located in Sorocaba, Sao Paulo state $\left(23^{\circ} 30^{\prime} 21^{\prime \prime} \mathrm{S}\right.$, $47^{\circ} 26^{\prime} 17^{\prime \prime} \mathrm{W}$ ) was opened in 1968. It occupies $130,000 \mathrm{~m}^{2}$ and contemplates about 1,200 species with 255 specimens from 69 mammals' species. Samples from the file sera of the park (collected and kept frozen since 2007) as samples collected from 2009 to
2010 at the routine of the zoo park were included at the research because of the variety of serology to leptospirosis.

Sampling was performed during veterinary routine at Sorocaba Zoo, Sorocaba, São Paulo State, in the period from 2007 to August 2010 totalizing 229 serum samples from 43 species of captive mammals and synanthropic animals, 35 blood samples from 15 species of captive mammals, five urine samples from four species of captive mammals and tissue samples from four wild animals that died at the zoo. Thirty serum samples from zoo staff were also collected and assayed for the research of antibodies to Leptospira spp. in 2010.

Blood samples were collected by venipuncture (jugular or femoral vein), centrifuged at $1,600 \times \mathrm{g}$ for 10 minutes, and sera samples were kept at $-20^{\circ} \mathrm{C}$ until serological tests were performed in 2010. Urine samples were collected in 2009 and 2010, by cystocentesis and immediately cultivated in Fletcher hemi-solid medium and evaluated weekly both macro and microscopically (Faine et al. 1999). Still, $0.5 \mathrm{~mL}$ were neutralized with buffered saline pH7.2 at proportion 1:1 in microtube, kept at $4^{\circ} \mathrm{C}$ until being centrifuged at $11,000 \mathrm{xg}$ for five minutes to eliminate residuals (in up to 24 hours) and kept at $-80^{\circ} \mathrm{C}$ until DNA extraction be performed.

All samples, including serum, whole blood, urine and fragments were frozen and then analyzed at the same time, using leptospires cultures from the same week to perform MAT and the same lot of reagents to the other employed techniques.

Leptospirosis serology was performed using the gold-standard serological test microscopic agglutination test (MAT) using 29 live antigens for antibody detection. Antigens were maintained in EMJH (Ellinghausen-MacCullough-Johnson-Harris) medium supplemented with filtered and inactivated rabbit serum and used in about 14 days of culture. Cut-off used was titer 100 and positive and negative controls were included (Faine et al. 1999).

DNA extraction of blood and urine samples were performed using a kit (Illustra blood genomicPrep Mini Spin, GE Healthcare, Buckinghamshire, UK) and from tissue samples kit Illustra tissue \& cells genomicPrep Mini Spin (GE Healthcare, Buckinghamshire, UK) was used. To DNA amplification specific primers to a fragment of $242 \mathrm{bp}$ from lipL32 gene from pathogenic species genome (Sttodard et al. 2009) were used and their nucleotidic sequences were: LipL32-45F 5'-AAGCATTACCGCTTGTGGTG-3'; LipL32-286R 5'-GAACTCCCATTTCAGCGATT-3'.

Amplification was made in MasterCycler gradient (Eppendorf) in a final volume of reaction of $25 \mu \mathrm{L}$. Reaction mix included $50 \mathrm{mM}$ of $\mathrm{KCl}, 10 \mathrm{mM}$ of Tris- $\mathrm{HCl}$ (pH 8.0), $1.5 \mathrm{mM}$ of $\mathrm{MgCl}_{2}, 1 \mu \mathrm{M}$ of each primer (LipL32-45F e LipL32-286R), $200 \mu \mathrm{M}$ of each dNTP (dATP, dTTP, dCTP and dGTP) and 1U of Taq Platinum DNA Polimerase (Invitrogen, Carlsbad, CA, USA). Mix volume was corrected with ultra-pure water to a final volume of $23 \mu \mathrm{L}$ and then $2 \mu \mathrm{L}$ of extracted DNA (10ng) was added. The first cycle was denaturation at $94^{\circ} \mathrm{C}$ for three minutes, primers annealing at a $63^{\circ} \mathrm{C}$ for one minute and extension at $72^{\circ} \mathrm{C}$ for two minutes. The 30 following cycles were: denaturation at $94^{\circ} \mathrm{C}$ for one minute, primers annealing at $63^{\circ} \mathrm{C}$ for one minute and extension at $72^{\circ} \mathrm{C}$ for two minutes. One final step at $72^{\circ} \mathrm{C}$ for 10 minutes resulted in full primers extension. This reaction generated PCR products of $242 \mathrm{bp}$ (MÉRIEN et al. 1992). All reactions were followed by negative and positive controls. Electrophoresis was performed to identify positive and negative samples.

An epidemiological inquiry was performed to evaluate the risk factors of infection including characteristics as animal origin (free-ranging or captive), gender, age, presence of domestic and synanthropic animals in cages and kind and availability of feeding. The association between epidemiological variables and serological results were analyzed by Chi-square and Fischer`s exact tests, considering $\alpha=0.05$ (Triola 2005). All tests were performed 
Table 1. Leptospirosis serology results in captive mammals from Sorocaba Zoo

\begin{tabular}{lccccc}
\hline \multicolumn{1}{c}{ Species } & Common name & $\mathrm{N}$ & $\mathrm{n}$ & $\mathrm{R}$ & Serovars (Titer) \\
\hline Alouatta caraya & Black howler monkey & 3 & 3 & $1 / 3$ & BUT (1) \\
Ateles marginatus & White faced spider monkey & 6 & 6 & $2 / 6$ & ICT (1); COP (2) \\
Brachyteles arachnoides & Woolly spider monkey & 5 & 9 & $1 / 9$ & BRA (1) \\
Cerdocyon thous & Crab-eating fox & 10 & 14 & $2 / 14$ & SEN (1, 2) \\
Chrysocyon brachyurus & Maned Wolf & 2 & 16 & $1 / 16$ & CAN (1) \\
Lagothrix lagotricha & Woolly monkey & 3 & 4 & $1 / 4$ & DJA (1), ICT (4), POM (1) \\
Nasua nasua & Coati & 5 & 11 & $2 / 11$ & CAN (1), COP (1) \\
Puma yagouarondi & Jaguarundi & 4 & 8 & $1 / 8$ & SEN (1) \\
Tapirus terrestris & Tapir & 3 & 4 & $2 / 4$ & POM (4; 16), ICT (4; 16)
\end{tabular}

$\mathrm{N}=$ Specimens number, $\mathrm{n}=$ Samples number, $\mathrm{R}=$ Reagent Samples/Samples number, BUT = Butembo, BRA $=$ Bratislava, CAN = Canicola, COP $=$ Copenhageni, DJA = Djasiman, ICT = Icterohaemorrhagiae, $\mathrm{POM}=$ Pomona, sem $=$ Sentot. Titer expressed in $1 \times 10^{2}$.

in Epilnfo ${ }^{\mathrm{TM}}$ v.3.5.1 program (Center for Diseases Control - CDC, Atlanta, USA, 2002). Another inquiry was performed to evaluate the level of knowledge of zoo staff about leptospirosis.

\section{RESULTS}

Out of 229 serum samples from captive mammals at Sorocaba Zoo, 13 (5.68\%; CI95\% 3.37-9.47\%) were reagent to one or more leptospires serovars, with titer ranging from 100 to 1,600 IU. Reagent animals with their respective serovars and titers, as the number of specimens by species are shown in Table 1. Some of animals had more than one sample and they were included in the study, due to epidemiology importance.

Out of 14 non-human primates species analyzed, individuals from four species were reagent including: one adult, free-ranging black howler monkey; two white faced spider monkey, one female and other male, both adult and free-ranging; one male, free-ranging Woolly spider monkey, serologically positive to serovar Bratislava in 2007, and after 2.5 years, in 2009, was not reagent; and one male, juvenile Woolly monkey.

Among carnivores, one female, adult, free-ranging crab-eating fox had titer 200 to serovar Sentot and after two months titer to the same serovar was 100; one adult, female, free-ranging maned wolf had titer 100 to serovar Canicola, one male, adult, born in captive coati had titer 100 to serovar Canicola and other male, adult, free-ranging coati had titer 100 to serovar Copenhageni; and one female, adult, free-ranging jaguarundi had titer 100 to serovar Sentot.

Among Peryssodactyla, one female, adult, captive born tapir showed titer 1,600 to Pomona and Icterohaemorrhagiae serovars in 2007 sampling and in paired serology performed in 2009; titers to the same serovars were 100 and 400 , respectively.

Sera samples from synanthropic animals were seronegative including: three white-eared opossums (Didelphis albiventris), five big-eared opposums (D. aurita); nine common opposums (D. marsupialis) and two domestic cats (Felis catus). Whole blood, urine and tissue samples submitted to PCR were also negative. The same way the only urine sample cultivated in Fletcher medium was negative.

All serum samples from zoo staff serum samples were not reagent to all tested leptospira serovars. This staff plays different kind of work at the zoo including cleaning and ge- neral services, keepers from different park sections, biologists, veterinary doctors and a municipal police.

\section{DISCUSSION}

Although professional efforts to keep a rigorous health management, zoological environment is propitious to many agents spread including zoonotic ones (Fowler 1993). Leptospirosis is an emergent zoonosis, considered endemic in tropical countries as Brazil. This fact added the high Brazilian biological diversity must encourage studies about leptospirosis in wild animals, once few is known about the role of these animals in the epidemiology of this disease.

Leptospirosis prevalence in mammals from Sorocaba Zoo was $5.68 \%$ considered the lowest when compared to those found in other Brazilian zoological parks as $37.7 \%$ at the Rio de Janeiro Zoo (Lilenbaum et al. 2002), 19.5\% at the São Paulo Zoo (Corrêa et al. 2004), 49.5\% at Bela Vista Sanctuary (Guerra-Neto et al. 2004) and 3.5\% (Ullmann et al. 2007), 10.2\% at the Uberaba Zoo (Esteves et al. 2005), 12.5 at the Aracaju Zoo (Pimentel et al. 2009) and 26.5\% at the Ribeirão Preto Zoo (Silva et al. 2010). This variation depends on many customs in each park, like management, contacts, feeding, i.e. Prevalences of $52 \%$ and $25 \%$ were found at the Chapultec Zoo in Mexico (Luna-Alvarez et al. 1996) and at the Korean Municipal Zoo (Jung et al. 2007), respectively.

The most prevalent serovar was Icterohaemorrhagiae, present in $25 \%$ animals, different from observed at the Rio de Janeiro Zoo, 27/29 (93.10\%) reacted to serovar Copenhageni and only one to Icterohaemorrhagiae (Lilenbaum et al. 2002). At the São Paulo Zoo, 15/59 (25.42\% CI95\% 16.07-37.86\%) reacted to serovar Copenhageni, 13/59 (22.03; CI95\% 13.38-34.20\%) to Pomona and 10/59 (16.95\%; CI95\% 9.5-28.52\%) to Castellonis (Corrêa et al. 2004). Copenhageni and Icterohaemorrhagiae serovars belong to the same serogroup, Icterohaemorrhagiae, and they are the most prevalent serovars in Brazilian urban centers (Pereira et al. 2000). Canicola, Icterohaemorrhagiae and Andamana serovars were the most frequent at Uberaba Zoo (Esteves et al. 2005) and Canicola, Icterohaemorrhagiae and Panama, as well as Patoc (non pathogenic) serovars were the most frequent at Ribeirão Preto Zoo (Silva et al. 2010). In all studies there were reagent animals to serovars that have rodents as reservoirs, highlighting the importance of rodent control in zoo parks, inserted mos- 
tly in urban centers, where rodents are abundantly spread (Faine et al. 1999).

Seroprevalence results are variable among different zoological parks, as well as among different animal species of zoo squad, even from the same species or specimen. The multiple etiology of leptospirosis, the reservoir role and environment contribute to the importance of seroepidemiological studies to understand the etio-epidemiology of leptospirosis.

Only one specimen of maned wolf out of two analyzed was seropositive at the Sorocaba Zoo and other paired samples analyzed during the period of study were seronegative, indicating only contact with leptospires, probably from the environment, similar found at the Uberaba Zoo, where the unique maned wolf analyzed was reagent (Esteves et al. 2005) and 3/4 specimens analyzed at the Rio de Janeiro Zoo were seropositive (Lilenbaum et al. 2002).

Two out of $10 \mathrm{crab}$-eating foxes were seropositive from Sorocaba Zoo, 4/5 from Rio de Janeiro Zoo (Lilenbaum et al. 2002), 1/2 from Uberaba Zoo (Esteves et al. 2005) and the unique specimen from Sergipe Zoo (Pimentel et al. 2009).

Two of five coatis from Sorocaba Zoo were seropositive, similar to Rio de Janeiro Zoo results, where 3/7 was seropositive (Esteves et al. 2005) and different from two non reagent coatis at the Sergipe Zoo (Pimentel et al. 2009).

One of four jaguarundis from Sorocaba Zoo was seropositive. Felids were serologically analyzed against Leptospira spp. antibodies at the Rio de Janeiro Zoo after the occurrence of one clinical case in a puma (Puma concolor), and $1 / 2$ jaguarundi was positive (Lilenbaum et al. 2004). One ocelot (Leopardus pardalis) and one margay (Leopardus wiedii) were seropositive at Bela Vista Sanctuary, among 57 neotropical felids analyzed (Ullmann et al. 2007). The performed study with 359 felids from 41 cities from São Paulo, Minas Gerais and Rio de Janeiro states showed 46 seropositives. However none jaguarundi was analyzed (Guerra-Neto 2004).

Serological results found in tapirs must be highlighted because the reagent samples belong to the same animal collected in an interval of 2.5 years. None tapir that inhabit the same enclosure was reagent what indicates that the positive animal must not act as reservoir in this environment. Titers found in the second sample can be residual or new expositions to the agent occurred among the obtaining the first and second sample. In domestic animals antibodies titers decrease and many times disappear around six months, and this animal kept titer, although in lower levels for more than two years. There is no study in relation to anti-Leptospira spp. antibodies titration and titers maintenance in wild animals to a deeply discussion. At the Rio de Janeiro Zoo the unique tapir specimen analyzed was negative to tested serovars (Lilenbaum et al. 2002).

Comparison among different leptospirosis prevalence in different zoo parks is complex due to the range of species, number of specimens, serovar variation and geographical area where zoo parks are placed.

Epidemiological analysis correlation with serological results obtained was not statistically significant with exception to wild animals' synanthropic to the park enclosures, where free-ranging birds and non-human primates were seen. Besides the few bird importance to leptospirosis, recent studies demonstrate seropositivity in birds kept in captive at the Ribeirão Preto Zoo (Silva et al. 2010). However besides the significant statistic difference found in the present study, authors believe that it was a coincidence once the enclosures were free-ranging birds and non-human primates were observed could also allow the entry of other important leptospires carriers as rodents.

Spiroquete isolation from urine is complex due to the low growing, presence of contaminant agents, disease phase and due to the intermittence of leptospires shedding (Adler \& Moctezuma 2010). Although only one urine sample had been cultivated resulting negative added the low seroprevalence found at the Sorocaba Zoo it is suggested that wild mammals do not act as source of infection in the studied place. Due to the protocol used to urine samples to PCR analysis a small number of samples was obtained. Primers used to molecular study were specific to pathogenic leptospira species and they amplified a fragment of lipL32 gene (Sttodard et al. 2009).

In the present study serologic, microbiologic and molecular methods were combined to attempt of know the epidemiology of leptospirosis at the zoological park, what is recommended due to the complementarity of techniques (Kee et al. 1994, Kositanont et al. 2007).

All serum samples from Sorocaba Zoo staff were non-reagent at MAT, equal result found at the Uberaba Zoo staff (Esteves et al. 2005) and Ribeirão Preto Municipal Park staff (Silva et al. 2010), what can occurred due to the fact of captive wild animals do not act as reservoirs and implemented preventive measures used by them to prevent transmission besides activities developed in animals enclosures.

In relation to the epidemiologic inquiry applied to zoo staff, rat was incriminated as the main transmissor, what is according to literature (Faine et al. 1999). Cat, on the other hand, was assigned by 12 staff $(29.27 \%)$ and this species is considered refractory to leptospirosis (Langoni et al. 1998). Besides the wide propagation about leptospirosis by media, $36.58 \%$ of interviewed do not know the main symptoms of leptospirosis.

Cats and dogs feces and mosquitoes were assigned as risk factors for leptospiral infection by $19.51 \%, 12.19 \%$ and $12.19 \%$ of interviewed, respectively. Feces are not considered as important shedding route, contrary to urine. Leptospirosis transmission is not transmitted by mosquitos' bite, different from dengue, other widely spread disease that occurs in outbreaks in rainfall season similar to leptospirosis. Most part of interviewed has just elementary education what can justify the lower knowledge level. No other study was conducted about the knowledge of leptospirosis with zoological park staffs.

New studies must be encouraged and performed both with captive as free-ranging wild animals, not only about leptospirosis but also to other infectious diseases.

\section{CONCLUSIONS}

Leptospirosis occurs in captive environment at different levels in many species as observed in the present study. 
Low seroprevalence found in captive mammals, negative results from urine and blood samples at PCR, and seronegativity found in zoo staff suggest that besides leptospires are present at the park; wild mammals do not act as source of infection to other wild animals and Sorocaba Zoo staff.

Acknowledgments.- To the State of São Paulo Research Foundation (FAPESP), for MSc grant (Process \# 2008/08781-3). We also kindly thank the help given by Sorocaba Zoo staff for the sample collection and storage, especially to Ramiro das Neves Dias Neto, Dr. Rodrigo H.F. Teixeira and Dr. Adauto Veloso Nunes.

\section{REFERENCES}

Adler B. \& Moctezuma A.P. 2010. Leptospira and leptospirosis. Vet. Microbiol. 140:287-296.

Bharadwaj R. 2004. Leptospirosis - a reemerging disease? Indian J. Med. Res. 120:136-138.

Bharti A.R., Nally J.E., Ricaldi J.N., Matthias M.A., Diaz M.M., Lovett M.A., Levett P.N., Gilman R.H., Willig M.R., Vinetz J.M. \& Peru-United States Consortium 2003. Leptospirosis: a zoonotic disease of global importance. Lancet, Infect. Dis. 3(12):757-771.

Bourhy P., Collet L., Clément S., Huerre M., Ave P., Giry C., Pettinelli F. \& Picardeau M. 2010. Isolation and characterization of new Leptospira genotypes from patients in Mayotte (Indian Ocean). PLoS Negl. Trop. Dis. 4(6):724.

Corrêa S.H.R., Vasconcellos S.A., Morais Z., Teixeira A.A., Dias R.A., Guimarães M.A.B.V., Ferreira F. \& Ferreira-Neto J.S. 2004. Epidemiologia da leptospirose em animais silvestres na Fundação Parque Zoológico de São Paulo. Braz. J. Vet. Res. Anim. Sci. 41:189-193.

Esteves F.M., Guerra-Neto G., Girio R.J. da S., Silva-Vergara M.L. \& Carvalho A.C. de F.B. 2005. Detecção de anticorpos para Leptospira spp. em animais e funcionários do Zoológico Municipal de Uberaba, MG. Arqs Inst. Biológico, São Paulo, 72(3):283-288.

Faine S., Adler B., Boein C. \& Perolat P. 1999. Leptospira and Leptospirosis. $2^{\text {nd }}$ ed., MedSci, Melbourne, Australia.

Fowler M.E. 1993. Zoo and Wild Animal Medicine. $3^{\text {rd }}$ ed. W.B. Saunders, Philadelphia. 617p.

Guerra-Neto G., Girio R.J.S., Andrade T.M., Koproski L.P., Moraes W. \& Santos L.C. 2004. Ocorrência de anticorpos contra Leptospira spp. em felídeos neotropicais pertencentes ao Criadouro de Animais Silvestres a Itaipu Binacional e ao Zoológico Municipal Bosque Guarani, Foz do Iguaçu, Estado do Paraná. Ars Vet. 20:75-80.

Jung B.Y., Choi J.S., Kim K.T., Song Y.K., Lee S.H., Lee K.W., Kim J.Y. \& Moon O.K. 2007. Seroprevalence of Leptospirosis in Korean Municipal Zoo Animals J. Vet. Med. Sci. 69(8):861-867.

Kee S.H., Kim I.S., Choi M.S. \& Chang W.H. 1994. Detection of leptospiral DNA by PCR. J. Clin. Microbiol. 32(4):1035-1039.

Kositanont U., Rugsasuk S., Leelaporn A., Phulsuksombati D., Tantitanawat S. \& Naigowit P. 2007. Detection and differentiation between pathogenic and saprophytic Leptospira spp. by multiplex polymerase chain reaction. Diagn. Microbiol. Infect. Dis. 57(2):117-122.

Ko A.I., Goarant C. \& Picardeau M. 2009. Leptospira: the dawn of the molecular genetics era for an emerging zoonotic pathogen. Natl Ver. Microbiol. 7:736-747.

Langoni H., Cabral K.G. \& Kronfly C.S. 1998. Pesquisa de aglutininas anti-leptospíricas em gatos. Clín. Vet. 17:20-28.

Levett P.N. 2001. Leptospirosis. Clin. Microbiol. Ver. 14(2):296-326.

Lilenbaum W., Monteiro R.V., Ristow P., Fraguas P., Cardoso V.S. \& Fedullo L.P.L. 2002. Leptospirosis antibodies in mammals from Rio de Janeiro Zoo, Brazil. Res. Vet. Sci. 73:319-321.

Lilenbaum W., Monteiro R.V., Albuquerque C.E. \& Ristow P. 2004. Leptospiral antibodies in wild felines from Rio de Janeiro Zoo, Brazil. Vet. Journal 168:191-193.

Luna-Alvarez M.A., Moles-Cervantes L.P., Torres-Barranca J.I. \& Guall-Sill F. 1996. Investigación serológica de leptospirosis en fauna silvestre mantenida en cautiverio en el zoológico de Chapultepec de la Ciudad de México. Vet. México 27(3):229-34.

Mérien F., Amouriaux P., Perolat P., Baranton G. \& Saint Girons I. 1992. Polymerase chain reaction for detection of Leptospira spp. in clinical samples. J. Clin. Microbiol. 30:2219-2224.

Pereira M.M., Matsuo M.G.S., Bauab A.R., Vasconcelos S.A., Moraes Z.M., Baranton G., Girons I. 2000. A clonal subpopulation of Leptospira interrogans sensu stricto is the major cause of leptospirosis outbreaks in Brazil. J. Clin. Microbiol. 38:450-452.

Pimentel J.S., Gennari S.M., Dubey J.P., Marvulo M.F.V., Vasconcellos S.A., Morais Z.M., Silva J.C.R. \& Neto J.E. 2009. Inquérito sorológico para toxoplasmose e leptospirose em mamíferos selvagens neotropicais do Zoológico de Aracaju, Sergipe. Pesq. Vet. Bras. 29(12):1009-1014.

Sharma S., Vijayachari P., Sugunan A.P. \& Sehgal S.C. 2003. Leptospiral carrier state and seroprevalence among animal population - a cross-sectional sample survey in Andamana and Nicobar Islands. Epidemiol. Infect. 131:985-989.

Silva C.S., Gírio R.J.J., Guerra-Neto G., Brich M., Santana L.A.S., Amâncio F.H., Mariani J.R. \& Wessort P.M.F. 2010. Anticorpos anti-Leptospira spp. em animais selvagens do zoológico municipal de Ribeirão Preto, estado de São Paulo, Brasil. Braz. J. Vet. Anim. Sci., 47(3):237-242.

SZB. 2012. Sociedade dos Zoológicos do Brasil. Congresso Anual de 2012, Belém-PA.

Sttodard R.A., Gee J.E., Wilkins P.P., McCaustland K. \& Hoffmaster A.R. 2009. Detection of pathogenic Leptospira spp. though TaMan polymerase chain reaction targeting the LipL32 gene. Diagn. Microbiol. Infect. Dis. 64:247-255.

Triola M.F. 2005. Introdução à estatística. 9ạ ed. LTC., Rio de Janeiro. 682p.

Ullmann L.S., Hoffmann J.L., Moraes W., Cubas Z.S., Santos L.C., Silva R.C., Camossi L.G., Moreira N., Guimaraes A.M.S., Montaño P., Langoni H. \& Biondo A.W. 2007. Prevalence of Leptospira interrogans antibodies in captive wildcats of Southwestern Brazil. XXXI Congresso da Sociedade de Zoológicos do Brasil, XIV Congresso da Associação Latinoamericana de Parques Zoológicos e Aquários e XVI Encontro da Associação Brasileira de Veterinários de Animais Selvagens, São Paulo, SP. 